\title{
Erratum
}

\section{Erratum to: The Effects on Dermal Wound Healing Using Novel Peptide Modified by Bone Morphogenic Protein-2}

\author{
Yoonjung Hong ${ }^{1} \cdot$ Hyeeun Shim ${ }^{2}$ Sehee $\mathrm{Kim}^{2} \cdot$ Narae $\mathrm{Choi}^{1} \cdot$ Jinsung $\mathrm{Kim}^{3}$. \\ Jiwon Hwang ${ }^{4} \cdot$ Jeongho Yun ${ }^{5} \cdot$ Bosun $\mathrm{Kwon}^{1,2}$ \\ ${ }^{1}$ Research Institute, Winnova Co., Ltd., Seoul, Republic of Korea \\ ${ }^{2}$ Research Institute, Wooridul Life Sciences Ltd., Seoul, Republic of Korea \\ ${ }^{3}$ Neurosurgery, Seoul St. Mary's Hospital of the Catholic University, Seoul, Republic of Korea \\ ${ }^{4}$ Department of Life science, Ewha womans University, Seoul, Republic of Korea \\ ${ }^{5}$ Division of Periodontology, Department of Dentistry, School of Medicine, Inha University, Incheon, Republic of Korea
}

(c) Tissue Engineering and Regenerative Medicine 2014

Erratum to: Tissue Engineering and Regenerative Medicine (2014), 11(5): pp 397-404

DOI 10.1007/s13770-014-0037-4

originally published article. Please find the correct

There was an error in the affiliation section of the affiliation in this erratum.

The online version of the original article can be found under DOI: 10.1007/s13770-014-0037-4

\section{${ }^{*}$ Corresponding author}

e-mail: bskwon9@gmail.com (Bosun Kwon)

Research Institute, Wooridul Life Sciences Ltd., Seoul,

Republic of Korea 